\title{
Low Geographic and Subspecific Variation in the Loud Call of the Widespread and Phenotypically Cryptic Northern Lesser Galago (Galago senegalensis) Suggests Taxonomic Uniformity
}

\author{
Magdalena S Svensson a, Thomas M Butynski ${ }^{\text {a,b }}$, Yvonne A de Jong Y ${ }^{\text {a,b }}$, Simon K Bearder a ${ }^{\text {, Irena }}$ \\ Schneiderová ${ }^{c, d}$, Vincent Nijman ${ }^{\text {a }}$ \\ ${ }^{a}$ Nocturnal Primate Research Group, Oxford Brookes University, Oxford, United Kingdom \\ beastern Africa Primate Diversity and Conservation Program, Nanyuki, Kenya \\ 'Department of Animal Science and Food Processing, Faculty of Tropical Agrisciences, Czech University of Life Sciences, \\ Prague, Czech republic \\ dPrague Zoological Garden, Prague, Czech republic
}

Key words: Advertisement calls, Bioacoustics, Biogeography, Bushbaby, Isolation by distance, Vocalisations

Short running title: Variation in Loud Call of Galago senegalensis

\begin{abstract}
Like other nocturnal primates, many species of galago (Galagidae) are phenotypically cryptic, making their taxonomic status difficult to resolve. Recent taxonomic work has disentangled some of the confusion. This has resulted in an increase in the number of recognised galago species. The most widespread galago species, and indeed the most widespread nocturnal primate, is the northern lesser galago (Galago senegalensis) whose geographic range stretches $>7,000 \mathrm{~km}$ across Africa. Based on morphology, 4 subspecies are currently recognised: G. s. senegalensis, G. s. braccatus, G. s. sotikae and G. s. dunni. We explore geographic and subspecific acoustic variation in G. senegalensis, testing three hypotheses: isolation by distance, genetic basis, and isolation by barrier. There is statistical support for isolation by distance for 2 of 4 call parameters (fundamental frequency and unit length). Geographic distance explains a moderate amount of the acoustic variation. Discriminant function analysis provides some degree of separation of geographic regions and subspecies, but the percentage of misdesignation is
\end{abstract}


high. Despite having (putative) parapatric geographic ranges, the most pronounced acoustic differences are between $G$. s. senegalensis and G. s. dunni. The findings suggest that the Eastern Rift Valley and Niger River are significant barriers for G. senegalensis. The acoustic structures of the loud calls of 121 individuals from 28 widespread sites are not significantly different. Although this makes it unlikely that additional unrecognised species occur within G. senegalensis at the sites sampled, vast areas of the geographic range remain unsampled. We show that wide-ranging species do not necessarily exhibit large amounts of variation in their vocal repertoire. This pattern may also be present in nocturnal primates with smaller geographic ranges.

\section{INTRODUCTION}

Geographic variation and dialects in vocalizations have been described within many species of vertebrates (e.g., Anura [Velásquez, 2014]; Psittaciformes [Brigham and Cebek, 1989]; Cetacea [Ford, 1991]; Chiroptera [Wright and Dahlin, 2018]; Rodentia [Slobodchikoff et al., 1998]). Intraspecies variation arises when differences in acoustic structure are larger among populations than within populations. While geographic variation relates to isolated populations, dialects arise in populations where gene flow is not restricted by distance or geographic barriers [Conner, 1982]. In primates, intraspecies geographic acoustic variation or dialects is documented for many taxa, including robust chimpanzees (Pan troglodytes) [Mitani et al., 1999], orang-utans (Pongo spp.) [Delgado et al., 2003], silvery gibbons (Hylobates moloch) [Dallmann and Geissmann, 2009], Japanese macaques (Macaca fuscata) [Green, 1975], vervet monkeys (Chlorocebus pygerythrus) [Price et al., 2014], Thomas's langurs (Presbytis thomasi) [Wich et al., 2008], red-chested moustached tamarins (Saguinus labiatus) [Maeda and Masataka, 1987], and small-eared greater galago (Otolemur garnettii) [Bettridge et al., in press]. Although there is ample evidence of intraspecies geographic variation in primate vocalizations, mechanisms that contribute to this variation are poorly understood [Dallmann and Geissmann, 2009]. Morphology, ecological selection, sexual selection, cultural transmission, and neutral processes (e.g., 
genetic drift) all potentially contribute to intraspecies acoustic variation. Indeed, some of these factors contribute simultaneously [Wilkins et al., 2013]. Studying intraspecies variation is important as it can significantly contribute to understanding the evolutionary processes that lead to variation in phenotypic traits [Clink et al., 2018]. Rapidly speciating lineages, such as swordtail crickets (Trigonidiinae), cicadas (Cicadoidea), and green lacewings (Chrysopidae), are predominantly identified by their calls [Wilkins et al., 2013]. As such, intraspecies divergence in acoustic signals may play a key role in speciation [Wilkins et al., 2013]. Moreover, vocalizations are a reliable tool for identifying cryptic (often nocturnal) species such as bats [Jones and Van Parijs, 1993], nightjars (Caprimulgidae) [Turner, 2011], frogs [Yuan and Ramli, 2013], and small-bodied primates [Zimmermann et al., 1988; Braune et al., 2008; Burton and Nietsch, 2010].

Galagos (Galagidae) are small-bodied (50-1,700 g) nocturnal primates endemic to sub-Saharan Africa where they occur in forest, woodland, and bushland [Bearder and Masters, 2013; Butynski et al., 2013; Nekaris, 2013]. The taxonomy of the Galagidae has long been contentious, primarily because many members of this family are phenotypically cryptic. With the help of molecular techniques, comparative morphology, and behavioural comparisons, including bioacoustics, the taxonomy of this family is now better understood. There has been an increase in the number of species recognised within Galagidae: Schwarz [1931] recognised 5 species, Hill [1953] 6, Jenkins [1987] 7, Olson [1979] 11, Bearder et al. [1995] and Honess [1996] 17, Kingdon [1997] 18, Groves [2001] 23, Grubb et al. [2003] 24, Butynski et al. [2013] 18, Nekaris [2013] 18, and Rowe and Myers [2016] 20.

The galago, and indeed the nocturnal primate, with the widest $(>7,000 \mathrm{~km})$ and largest geographic range, the northern lesser galago (Galago senegalensis), occurs from the Atlantic Ocean in West Africa to the Red Sea and Indian Ocean in eastern Africa (Fig. 1) [Nash et al., 2013; Nekaris, 2013]. Based on morphological, behavioural, genetic, and acoustic data, 7 species have been split from G. senegalensis: southern lesser galago (Galago moholi), Somali lesser galago (Galago gallarum), spectacled lesser galago (Galago matschiei), Malawi dwarf galago (Paragalago nyasae), Zanzibar dwarf galago (Paragalago zanzibaricus), Mozambique dwarf galago (Paragalago granti), and Kenya coast dwarf 
galago (Paragalago cocos) [Zimmermann et al., 1988; Nash et al., 1989; Zimmermann, 1990; Anderson, 1999, 2001; Bearder, 1999; Anderson et al., 2000; DelPero et al., 2000; Masters and Bragg, 2000; Groves, 2001, 2005; Grubb et al., 2003; Butynski and De Jong, 2004; Roos et al., 2004; Masters et al., 2007; Nekaris and Bearder, 2011; Nash et al., 2013].

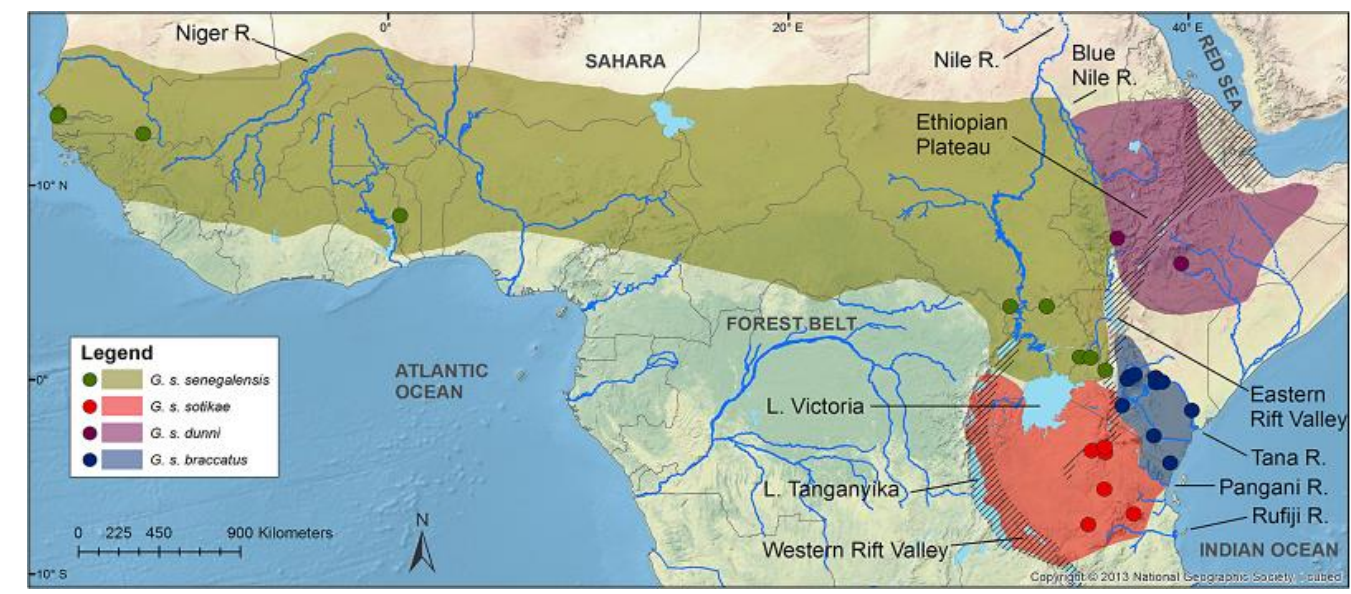

Fig. 1. Geographic ranges of the 4 subspecies of northern lesser galago (Galago senegalensis). Also shown are the sites at which honk calls were recorded and the more likely barriers to gene flow.

Species identification based on morphology is appropriate for animals that recognise one another by sight (as is typically the case for diurnal primates), but potentially problematic for nocturnal animals that mostly rely on scent and sound. Many nocturnal primates, including galagos, emit loud calls (also referred to as advertising calls or long-range calls) in the context of attracting companions and repelling rivals [Bearder et al., 1995]. The loud calls of galagos are highly species-specific and, therefore, are excellent tools for species identification [Masters, 1993; Bearder et al., 1995]. For example, formerly conspecific G. moholi and G. senegalensis were elevated to species level due to differences in their homologous loud calls and vocal repertoires [Zimmermann et al., 1988; Zimmermann, 1990; Bearder et al., 1995; Anderson et al., 2000]. Genetic data later confirmed this taxonomy [Pozzi et al., 2015]. The distinctive loud call of G. gallarum, previously considered a subspecies of G. senegalensis, confirmed its species status [Butynski and De Jong, 2004, 2013]. Recently, the Angolan dwarf galago (Galagoides kumbirensis) was recognised partly based on loud call and vocal repertoire [Svensson et al., 2017]. 
Although there is extensive information on species specificity of loud calls in galagos, there is little knowledge of intraspecies variation of these calls and mechanisms that contribute to this variation.

Galago senegalensis has an extensive vocal repertoire with at least 18 spectrographically different call types [Zimmermann, 1985; Zimmermann et al., 1988; Bearder et al., 1995]. Galago senegalensis belongs to the galago group of 'repetitive callers'. Its loud call, also referred to as the 'honk' or 'woo', is arranged at regular intervals into 'bouts'. Bouts may comprise hundreds of repeated honks [Bearder et al., 1995]. Vocal profile of G. senegalensis available at: http://www.wildsolutions.nl/vocalprofiles/galago/senegalensis/. Honk loud calls (hereafter referred to as honk call) show harmonic spectra with a fundamental frequency of about $400 \mathrm{~Hz}$ and slow frequency modulation. Honk calls can be heard by the human ear at >200 m under most conditions [Y. de Jong and T. Butynski, pers. observation] and are, therefore, suitable for long-distance communications among conspecifics [Zimmermann, 1985, 1995; Schneiderová et al., 2016]. Honk calls are emitted in gathering, contact, and display situations [Zimmermann, 1985; Bearder et al., 1995; Anderson et al., 2000; Svensson and Bearder, 2013]. Both sexes emit honk calls when leaving sleeping sites at dusk and when returning to sleeping sites at dawn, as well as throughout the night [Bearder et al., 2003]. Honk calls are particularly common during mating and birth periods [Bearder et al., 1995], and when population density is relatively high [Y. de Jong and T. Butynski, pers. observation]. Galago senegalensis is a particularly suitable species for investigating geographic and intraspecific vocal variation as it is polytypic, locally common, lives in a wide range of habitats, has a large geographic range with many potential barriers to gene flow, and has a honk call that is given in long bouts that are relatively easy to record and analyse.

In this study we examined variation in the honk call of G. senegalensis across the species' geographic range, across subspecies, and across potential geographic barriers. The taxonomic arrangement applied here for G. senegalensis is that of Groves [2001], Grubb et al. [2003], Butynski et al. [2013], and Nekaris [2013], who recognise 4 subspecies (Fig. 2): Senegal lesser galago (G. $s$. senegalensis), Kenya lesser galago (G. s. braccatus), Tanzania lesser galago (G. s. sotikae), and Ethiopia lesser galago (G. s. dunni). 

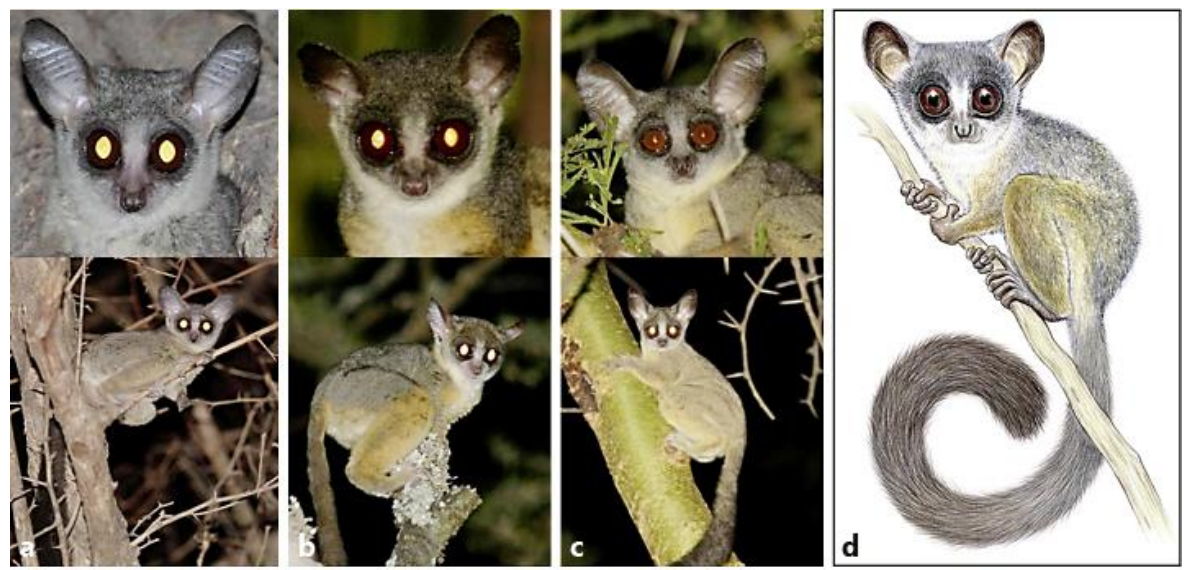

Fig. 2. Comparison of pelage colour and pattern, and ear length, of the 4 subspecies of northern lesser galago (Galago senegalensis): G. s. senegalensis, The Gambia (a); G. s. braccatus, central Kenya (b); G. s. sotikae, southwestern Kenya (c); G. s. dunni (d). Photographs by S.K. Bearder (a), Y.A. de Jong and T.M. Butynski (b and c). Drawing by Stephen Nash.

We tested three hypotheses, all of them based on the assumption that variation occurs within the honk call of G. senegalensis and that neutral processes contributed to this acoustic variation.

1 The isolation by distance hypothesis is based on the fact that differentiation among distant populations leads to evolutionary change [Wright, 1943]; a subspecies with a large geographic range is expected to have more within subspecies honk call variation than a subspecies with a small geographic range. In addition, a relationship between geographic distance and acoustic differences is expected throughout the range [e.g., Irwin et al., 2008; Campbell et al., 2010].

2 According to the genetic basis hypothesis, differences among the honk calls of the 4 subspecies have a genetic basis; honk call variation is expected to correspond to the 4 subspecies [e.g., Hill et al., 2013].

3 According to the isolation by barrier hypothesis, populations are isolated by geographic barriers (e.g., deep valleys, big rivers) [e.g., Baker et al., 2003]; geographic barriers are expected to explain honk call variation.

We also investigated the intraspecies variation of honk calls with respect to the potential existence of additional species and subspecies within G. senegalensis. 


\section{METHODS}

\section{Study Species and Regions}

Galago senegalensis, a medium-sized galago (adult body weight approx. 200 g) [Jenkins, 1987; Groves, 2001; Nash et al., 2013], forages and sleeps alone or in small groups. Solitary individuals are, however, part of social networks [Bearder et al., 2003; Nash et al., 2013; Nekaris, 2013]. Although the 4 G. senegalensis subspecies are phenotypically similar, with an understanding of the diagnostic traits (Fig. 2; Table 1) and experience, they can be visually distinguished in the field [De Jong and Butynski, 2018a]. Several geographic barriers appear to isolate, or partly separate, these 4 subspecies (Fig. 1):

$1 \quad$ G. s. senegalensis (type locality Senegal): limited by Atlantic Ocean in the west; north by Sahara Desert; east by western edge of Ethiopian Plateau, Blue Nile River, Eastern (Gregory) Rift Valley; south by northern edge of Masai Mara Plains, northern edge of Lake Victoria, forest belt.

2 G. s. braccatus (type locality Tsavo, Kenya): limited by Eastern Rift Valley in the west; north by arid region (including Chalbi Desert); east by Tana River, Indian Ocean; south by Pangani River, northern lower slopes of Mount Kilimanjaro/Mount Meru.

3 G. s. sotikae (type locality Telek River, Sotik, Kenya): limited by Western (Albertine) Rift Valley (particularly Lake Tanganyika) in the west; north by Pangani River, southern lower slopes of Mount Kilimanjaro/Mount Meru, southern lower slope of Mau Escarpment, southern edge of Lake Victoria, forest belt; east by Indian Ocean; south by Rufiji River, Udzungwa Mountains, Southern Highlands.

$4 \quad$ G. s. dunni (type locality Fafan River, Somalia): limited by western edge of Ethiopian Plateau, Blue Nile River, Eastern Rift Valley in the west; north by northern edge of Ethiopian Plateau; east by eastern edge of Ethiopian Plateau, arid region; south by arid region (including Chalbi Desert); southwest by Eastern Rift Valley. Competition with G. gallarum might be a limitation to the east and south.

Within the geographic range of G. senegalensis we recognise 4 regions: (1) west of the Niger River (only G. s. senegalensis); (2) between the Niger River and the Nile River (only G. s. senegalensis); 
(3) east of the Nile River and west of the Eastern Rift Valley (G. s. senegalensis, G. s. sotikae, G. s. dunni); (4) east of the Eastern Rift Valley and/or on the Ethiopian Plateau (G. s. braccatus, G. s. sotikae, G. s. dunni).

\begin{tabular}{|c|c|c|c|c|}
\hline & G. s. senegalensis & G. s. braccatus & G. s. sotikae & G. s. dunni \\
\hline Relative ear length & Medium & Short & Long & Short \\
\hline Forehead & $\begin{array}{l}\text { Grey, sometimes with } \\
\text { buff wash }\end{array}$ & Grey with russet w: & $\begin{array}{l}\mathrm{hGrey} \text {; yellow wash in } \\
\text { southern part of range }\end{array}$ & Grey or greyish-brown \\
\hline Dorsum & Grey & $\begin{array}{l}\text { Grey to brownish- } \\
\text { grey }\end{array}$ & $\begin{array}{l}\text { Brownish-grey with } \\
\text { yellow wash }\end{array}$ & Grey \\
\hline Flanks & Grey with yellow wash & $\begin{array}{l}\text { hGrey with intense } \\
\text { russet wash }\end{array}$ & $\begin{array}{l}\text { Greyish-brown with } \\
\text { yellow wash }\end{array}$ & Grey with yellow wash \\
\hline Outer lower hindlegs & $\begin{array}{l}\text { Grey, sometimes with } \\
\text { yellow wash }\end{array}$ & $\begin{array}{l}\text { Intense russet or } \\
\text { bright buff }\end{array}$ & $\begin{array}{l}\text { Grey, sometimes with } \\
\text { yellow wash }\end{array}$ & Grey with yellow wash \\
\hline $\begin{array}{l}\text { Delineation of colours } \\
\text { between upper and } \\
\text { lower outer hindlegs }\end{array}$ & s Weak or none & Sharp & None & Weak \\
\hline Base of tail & $\begin{array}{l}\text { Dark grey to greyish- } \\
\text { brown }\end{array}$ & $\begin{array}{l}\text { Brown with russet } \\
\text { wash }\end{array}$ & $\begin{array}{l}\text { Greyish-brown with } \\
\text { yellow wash }\end{array}$ & Grey \\
\hline Tip of tail & Blackish or brown & Blackish or brown & Dark grey or brown & Dark grey or brown \\
\hline
\end{tabular}

\section{Study Sites and Honk Call Recordings}

Galago senegalensis honk calls included in this study were recorded during 1994-2018 from wild individuals at 28 sites (Fig. 1; Table 2). Of 131 recordings, 121 were suitable for further analyses. Galagos were detected by their calls or eye shine and observed at close proximity when feasible, for as long as possible. Some of the galagos were habituated or became accustomed to researcher(s) within hours [e.g., Svensson and Bearder, 2013]. Since the honk calls were recorded by various researchers over a 24-year period, the recording equipment varied from high-quality cassette recorders to digital recorders. Some recordings were obtained by an audio recorder (AudioMoth by Open Acoustic Devices) [Hill et al., 2018]. As quality and completeness of recordings varied, there was a limit to the number of acoustic parameters that could be reliably measured. For instance, for many recordings it was not possible to 
assess whether the beginning and the end of the honk call were included. Hence, bout length, a call parameter commonly used in animal vocalization studies, was not considered in this study.

\begin{tabular}{|c|c|c|c|c|c|c|c|c|}
\hline Country & Site & $\begin{array}{l}\text { Sub } \\
\text { cies }\end{array}$ & Habitat & $\begin{array}{l}\text { Altitude, } \\
\text { m a.s.l. }\end{array}$ & $\begin{array}{l}\text { Mean } \\
\text { annual } \\
\text { rainfall }{ }^{1} \text {, } \\
\text { mm }\end{array}$ & $\begin{array}{l}\text { Mean annual } \\
\text { temperature }{ }^{1} \text {, } \\
{ }^{\circ} \mathrm{C}\end{array}$ & Recorded by & $\begin{array}{l}\text { Call } \\
\text { recordi } \\
\text { ngs, } n\end{array}$ \\
\hline \multirow[t]{13}{*}{ Kenya } & Kora NP & $\mathrm{b}$ & Bushland, woodland & 400 & 47 & 27 & Y.J./T.B. & 2 \\
\hline & Tsavo West NP & $\mathrm{b}$ & $\begin{array}{l}\text { Bushland, woodland, } \\
\text { grassland }\end{array}$ & 850 & 64 & 25 & Y.J./T.B. & 1 \\
\hline & Tana River Primate Nat R & $\mathrm{b}$ & $\begin{array}{l}\text { Forest, grassland, } \\
\text { woodland, bushland }\end{array}$ & 40 & 49 & 28 & T.B./Y.J. & 3 \\
\hline & Meru NP & $\mathrm{b}$ & $\begin{array}{l}\text { Forest, woodland, } \\
\text { bushland, grassland }\end{array}$ & 370 & 99 & 26 & Y.J./T.B. & 10 \\
\hline & Borana Ranch, Laikipia & $\mathrm{b}$ & $\begin{array}{l}\text { Woodland, bushland, } \\
\text { grassland }\end{array}$ & 1,900 & 97 & 18 & T.B./C.D.S. & 3 \\
\hline & Kithima Kia Mukuu NR, Isiolo & $\mathrm{b}$ & Bushland, woodland & 1,550 & 99 & 21 & Y.J./T.B. & 1 \\
\hline & North Kilimangodo, Kwale & $\mathrm{b}$ & $\begin{array}{l}\text { Bushland surrounded by } \\
\text { agriculture }\end{array}$ & 250 & 74 & 26 & Y.J./T.B. & 1 \\
\hline & Ololula Forest, Nairobi & $\mathrm{b}$ & Forest & 1,800 & 76 & 19 & T.B. & 1 \\
\hline & Chebseon, Southwest Mau FR & so & Forest & 2,350 & 95 & 19 & T.B. & 1 \\
\hline & Ol Pejeta Conservancy, Laikipia & $\mathrm{b}$ & $\begin{array}{l}\text { Woodland, bushland, } \\
\text { grassland }\end{array}$ & 1,800 & 114 & 16 & Y.J./T.B. & 2 \\
\hline & Saiwa Swamp NP & se & Forest & 1,850 & 94 & 18 & Y.J./T.B. & 2 \\
\hline & Mwingi Nat R & $\mathrm{b}$ & $\begin{array}{l}\text { Forest, bushland, } \\
\text { woodland }\end{array}$ & 510 & 62 & 26 & Y.J./T.B. & 5 \\
\hline & Tumbili Estate, Laikipia & $\mathrm{b}$ & Woodland, bushland & 1,800 & 56 & 25 & Y.J./T.B. & 5 \\
\hline \multirow[t]{6}{*}{ Tanzania } & Lake Manyara NP & so & $\begin{array}{l}\text { Grassland, woodland, } \\
\text { bushland }\end{array}$ & 970 & 44 & 22 & Y.J./T.B. & 1 \\
\hline & Ruaha NP & so & Woodland & 830 & 50 & 24 & P.H. & 2 \\
\hline & Lake Eyasi & so & Woodland & 1,040 & 51 & 22 & A.P. & 31 \\
\hline & Meia Meia & so & Woodland, bushland & 1,300 & 47 & 22 & Y.J./T.B. & 10 \\
\hline & Melela Nzuri, Morogoro & so & Woodland & 510 & 93 & 25 & Y.J./T.B. & 5 \\
\hline & Kwakachinja & so & Woodland & 985 & 48 & 22 & C.B. & 3 \\
\hline \multirow[t]{2}{*}{ Ethiopia } & Bidree Village & d & Woodland & 1,700 & 64 & 21 & T.B. & 4 \\
\hline & Kafa Biosphere Reserve & d & Forest, bamboo & 1,600 & 130 & 19 & K.S. & 1 \\
\hline \multirow[t]{3}{*}{ Uganda } & Mt Elgon NP & se & Forest, grassland, bamboo & 2,800 & 98 & 18 & L.A. & 2 \\
\hline & Agoro-Agu FR & se & Forest, woodland & 1,400 & 99 & 23 & Y.J./T.B. & 6 \\
\hline & Otzi FR & se & Forest, woodland & 1,290 & 90 & 26 & Y.J./T.B. & 3 \\
\hline Ghana & Kyabobo NP & se & Woodland, forest & 180 & 108 & 26 & S.B./J.T./R.P & P 5 \\
\hline Gambia & Niumi NP & se & Woodland, grassland & 2 & 73 & 28 & S.B./M.S. & 3 \\
\hline \multirow[t]{2}{*}{ Senegal } & Fathala WR & se & Woodland, grassland & 35 & 68 & 28 & I.S. & 6 \\
\hline & Fongoli & se & Woodland & 200 & 95 & 29 & G.E. & 2 \\
\hline
\end{tabular}

NP, National Park; NR, Nature Reserve; Nat R, National Reserve; FR, Forest Reserve; WR, Wildlife Reserve. b, G. s. braccatus; d, G. s. dunni; se, G. s. senegalensis; so, G. s. sotikae. A.P., Andrew Perkin; C.B., Caroline Bettridge; C.D.S., C. D. Schaaf; G.E., Grace Ellison; I.S., Irena Schneiderová; J.T., Jessica Tombs; K.S., Karina Schell; L.A., Lesley Ambrose; M.S., Magdalena Svensson; P.H., Paul Honess; R.P., Roland Plesker; S.B., Simon Bearder; T.B., Thomas Butynski; Y.J., Yvonne de Jong. ${ }^{1}$ Mean annual rainfall and mean annual temperature 1991-2015 (www.worldbank.org/climateportal). 


\section{Acoustic Analyses}

Honk calls were digitalised (if recorded by a cassette recorder) at a sample rate of $22.05 \mathrm{kHz}$ and 16-bit size and analysed using Avisoft SASLab Pro software (R. Specht, Berlin; version 5.2). Each recording was converted into a spectrogram, ensuring that only high-quality recordings were included in the analyses. Spectrogram parameters were set as follows: FFT length 512; 50\% overlap; hamming window, yielding time, and frequency measurement precision of $5.3 \mathrm{~ms}$ and $94 \mathrm{~Hz}$. Acoustic parameters measured from spectrograms of honk calls (Fig. 3) were: (a) mean dominant frequency (measured in Hz); (b) mean fundamental frequency (first harmonic, measured in $\mathrm{Hz}$ ); (c) mean unit length (basic element of a call that is represented as a continuous tracing along the temporal axis of the spectrogram, measured in seconds); and (d) mean interunit interval (time gap between 2 consecutive units along the temporal axis of a spectrogram, measured in seconds).

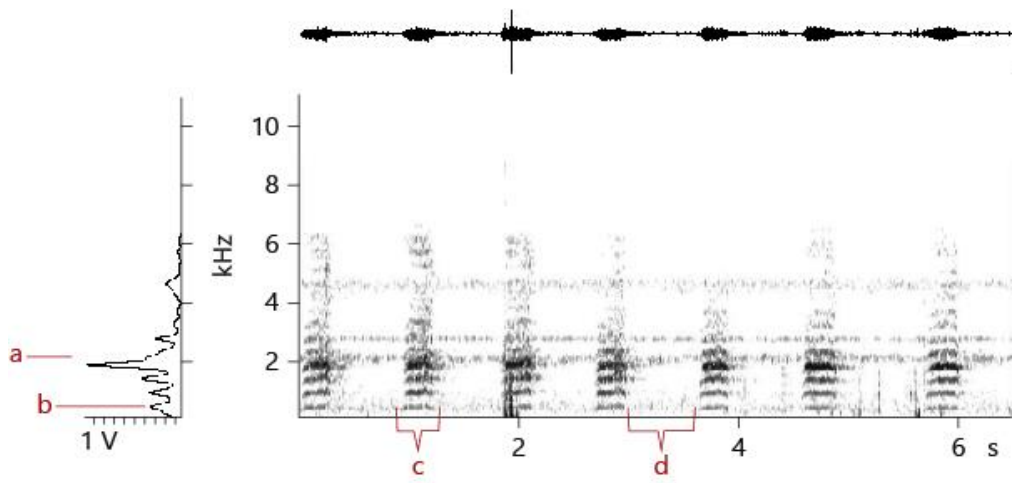

Fig. 3. Northern lesser galago (Galago senegalensis) honk call spectrogram showing the 4 call parameters included in this study: dominant frequency (a); fundamental frequency (b); unit length (c); interunit interval (d).

Intraindividual variation in unit length and interunit interval is considerably smaller than interindividual variation. More specifically, when measuring multiple unit lengths per call, the standard deviation was $7.78 \%$ of the mean value within individuals $(n=100)$ but $19.62 \%$ among individuals $(n=$ 121). Similarly, when measuring multiple interunit intervals per call, the standard deviation is $9.57 \%$ of the mean value within individuals $(n=99)$ but $21.52 \%$ among individuals $(n=121)$. Based on this, and to avoid non-independence when including multiple measurements from single individuals, we applied, for 
all 4 call parameters, the mean for individuals rather than the range. To help ensure that only 1 honk call bout per individual was analysed, we selected only 1 call per hour from the same location. While it is unlikely, we are, nevertheless, not absolutely certain that no individual provided more than 1 honk call bout to this study.

\section{Statistical Analyses}

To test the isolation by distance hypothesis, 2 high-quality calls were selected from each of 21 sites (Fig. 1) and compared against one another. Only 1 high-quality call was available from the remaining 7 sites. This resulted in a total of 49 recordings. Geographic distances of the 28 sites were measured in ArcMAP 10.4 and rounded up to the nearest $5 \mathrm{~km}$. Within-site calls were assumed to have been recorded at $<5 \mathrm{~km}$. For all 4 call parameters we measured differences among calls by subtracting the smallest value from the largest value and then divided that value by the largest difference measured (thus, expressing differences as a proportion of the maximum recorded difference). To approach a normal distribution, we log-transformed geographic distances and differences in call parameters. We calculated Pearson's correlation coefficient for the relationship between geographic distance and difference for the 4 call parameters separately and for their mean. Because data from each site were used in comparisons with all other sites, samples are not independent. To overcome this, we regrouped the 670 comparisons in 49 distance classes (i.e., equal to the original sample size), each containing 10-15 comparisons.

To test whether the observed variation can be explained by genetic basis (genetic basis hypothesis) or by separated geographic regions (isolation by barrier hypothesis), we applied multivariate analysis of variance. We compared the absolute measurements of the 4 call parameters using the geographic ranges of the 4 subspecies. In addition, call parameter measurements were taken of the 4 geographic regions. All useable calls $(n=121)$ were included in this analysis. This was followed by post hoc testing (Tukey) to determine which differences among subspecies and geographic regions were statistically significant.

In testing subspecies differences and the effects of geographic regions, we applied a canonical discriminant function analysis (DFA), applying all usable calls $(n=121)$. Four a priori recognised groups were used for testing subspecies differences and for testing the effects of geographic regions (groups as 
defined above). For both DFA analyses we extracted the first 2 functions. These explained 65.9 and $22.2 \%$ of the variance for subspecies, and 77.3 and $21.7 \%$ of the variance for geographic regions. In all analyses we accepted significance when $p$ was $<0.05$ in a two-tailed test.

\section{RESULTS}

\section{Isolation by Distance Hypothesis}

Apart from unit length and dominant frequency, which are weakly but significantly correlated $(R$ $=0.335, n=49, p=0.023$ ) (Table 3), the 4 call parameters are not correlated with each other (all Pearson's $R<0.208, n=49, p>0.165)$. Variation in call parameters, expressed as standard deviation divided by the mean or the range, shows no relationship with geographic range size. Therefore, G. $s$. senegalensis, the subspecies with the largest geographic range, does not have greater honk call variation than G. s. braccatus, the subspecies with the smallest range.

There is no significant relationship between geographic distance (log-transformed) and the difference in interunit interval (log-transformed) $(R=0.208, n=49, p=0.152$, Fig. $4 \mathrm{c}$ ) or dominant frequency (log-transformed) $(R=0.119, n=49, p=0.413$, Fig. 4 d). There is a highly significant positive relationship between geographic distance (log-transformed) and the difference in fundamental frequency (log-transformed) (Pearson's $R=0.507, n=49, p=0.0002$, Fig. 4a), unit length (log-transformed) $(R=$ 0.297, $n=49, p=0.0384$, Fig. $4 \mathrm{~b})$, and the 4 parameters combined $(R=0.511, n=49, p<0.0002$, Fig. 4e). The coefficient of determination is moderate to low $\left(R^{2}=0.257, R^{2}=0.088\right.$, and $R^{2}=0.261$, respectively). As such, geographic distance explains a moderate amount of the observed differences in fundamental frequency, unit length, and overall acoustic variation. 
Table 3. Means and standard deviations for 5 honk call parameters for each of the 4 subspecies of northern lesser galago (Galago senegalensis). Ranges in parentheses.

\begin{tabular}{llllll}
\hline Subspecies, $n$ & $\begin{array}{l}\text { Maximum } \\
\text { duration, } \mathrm{s}\end{array}$ & $\begin{array}{l}\text { Dominant } \\
\text { frequency, } \mathrm{Hz}\end{array}$ & $\begin{array}{l}\text { Fundamental } \\
\text { frequency, } \mathrm{Hz}\end{array}$ & $\begin{array}{l}\text { Unit length, } \\
\mathrm{s}\end{array}$ & $\begin{array}{l}\text { Interunit } \\
\text { interval, s }\end{array}$ \\
\hline G. s. senegalensis (29) & 124 & $\begin{array}{l}1,296 \pm 284 \\
(670-1,790)\end{array}$ & $\begin{array}{l}641 \pm 258 \\
(300-1,215)\end{array}$ & $\begin{array}{l}0.29 \pm 0.06 \\
(0.20-0.42)\end{array}$ & $\begin{array}{l}0.68 \pm 0.14 \\
(0.46-0.89)\end{array}$ \\
\hline G. s. braccatus (35) & 124 & $\begin{array}{l}1,038 \pm 348 \\
(350-1,630)\end{array}$ & $\begin{array}{l}580 \pm 206 \\
(320-1,060)\end{array}$ & $\begin{array}{l}0.24 \pm 0.04 \\
(0.18-0.33)\end{array}$ & $\begin{array}{l}0.80 \pm 0.17 \\
(0.51-1.17)\end{array}$ \\
\hline G. s. sotikae (52) & \multirow{2}{*}{94} & $\begin{array}{l}1,305 \pm 362 \\
(410-1,980)\end{array}$ & $\begin{array}{l}634 \pm 229 \\
(320-1,140)\end{array}$ & $\begin{array}{l}0.28 \pm 0.05 \\
(0.18-0.41)\end{array}$ & $\begin{array}{l}0.81 \pm 0.17 \\
(0.45-1.24)\end{array}$ \\
\hline G. s. dunni (5) & 28 & $\begin{array}{l}1,186 \pm 396 \\
(980-1,890)\end{array}$ & $\begin{array}{l}424 \pm 134 \\
(320-640)\end{array}$ & $\begin{array}{l}0.21 \pm 0.07 \\
(0.17-0.33)\end{array}$ & $\begin{array}{l}0.72 \pm 0.12 \\
(0.65-0.93)\end{array}$ \\
\hline
\end{tabular}
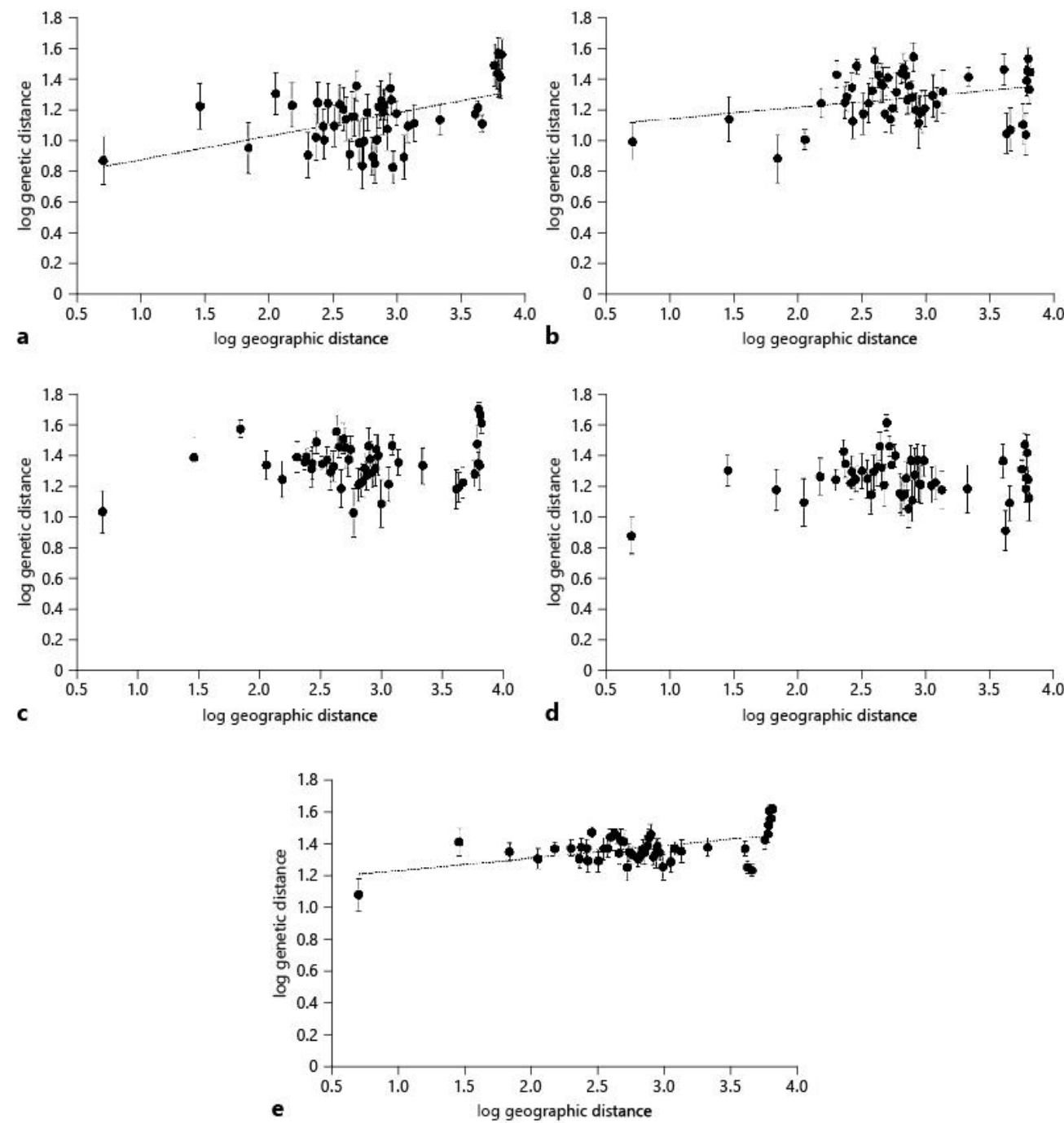

Fig. 4. Difference among 4 parameters of the honk call of individual northern lesser galagos (Galago senegalensis) in relation to geographic distance: fundamental frequency $(\mathbf{a})$; unit length (b); interunit intervals (c); dominant frequency (d); combined (e). Values are means \pm SEM. Note that for $\mathbf{a}, \mathbf{b}$, and $\mathbf{e}$, the relationship is statistically significant, but not for $\mathbf{c}$ and $\mathbf{d}$. As such, no trendline is presented for $\mathbf{c}$ and $\mathbf{d}$. 


\section{Genetic Basis Hypothesis}

There are significant acoustic differences among the honk calls of all 4 G. senegalensis subspecies $\left(F_{12,302}=4.326, p<0.001 ;\right.$ Wilk's $\lambda=0.657$, partial $\left.\eta^{2}=0.131\right)$, in unit length $\left(F_{3,117}=8.828, p<\right.$ $0.001)$, interunit interval $\left(F_{3,117}=3.993, p=0.010\right)$, and dominant frequency $\left(F_{3,117}=6.221, p=0.001\right)$, but not in fundamental frequency (Table 3). A Tukey post hoc test indicates that unit length is significantly different between G. s. senegalensis and G. s. braccatus $(p<0.001)$, between $G$. $s$. senegalensis and G. s. dunni $(p=0.007)$, between G. s. braccatus and G. s. sotikae $(p=0.002)$, and between $G$. s. sotikae and G. s. dunni $(p=0.022)$. For interunit interval, G. s. senegalensis differs significantly from G. s. braccatus $(p=0.045)$ and $G$. s. sotikae $(p=0.008)$. Finally, for dominant frequency, G. s. senegalensis differs significantly from G. s. braccatus $(p=0.012)$, and G. s. braccatus from G. s. sotikae ( $p<0.001$; Table 3).

The DFA designated, on average, $52.1 \%$ of the individual honk calls to the correct subspecies, whereas given that there are 4 subspecies, the prior probability for each subspecies is $25 \%$. Correct subspecies designation is highest for G. s. braccatus $(65.7 \%)$ and lowest for G. s. sotikae (44.2\%; Table 4). G.alago s. braccatus and G. s. dunni are separated from G. s. sotikae and G. s. senegalensis mostly on DFA function 1 (which correlates most strongly with unit length and dominant frequency). Galago s. braccatus and G. s. sotikae are separated from G. s. dunni and G. s. senegalensis mostly on DFA function 2 (which correlates most strongly with interunit length).

\begin{tabular}{|c|c|c|c|c|c|}
\hline Subspecies & senegalensis & braccatus & sotikae & dunni & Total \\
\hline G. s. senegalensis & $14(48.3)$ & $9(31.0)$ & $4(13.8)$ & $2(6.9)$ & 29 \\
\hline G. s. braccatus & $3(8.6)$ & $23(65.7)$ & $5(14.3)$ & $4(11.4)$ & 35 \\
\hline G. s. sotikae & $12(23.1)$ & $10(19.2)$ & $23(44.2)$ & $7(13.5)$ & 52 \\
\hline G. s. dunni & $1(20.0)$ & $1(20.0)$ & $0(0.0)$ & $3(60.0)$ & 5 \\
\hline Geographic region & $\begin{array}{l}\text { West of } \\
\text { Niger R. }\end{array}$ & $\begin{array}{l}\text { Between Niger R. } \\
\text { and Nile R. }\end{array}$ & $\begin{array}{l}\text { West of Eastern } \\
\text { Rift Valley }\end{array}$ & $\begin{array}{l}\text { East of Eastern } \\
\text { Rift Valley }\end{array}$ & Total \\
\hline West of Niger R. & $6(40.0)$ & $2(13.3)$ & $3(20.0)$ & $4(26.7)$ & 15 \\
\hline Between Niger R. and Nile R. & $0(0.0)$ & $1(33.3)$ & $0(0.0)$ & $2(66.7)$ & 3 \\
\hline West of Eastern Rift Valley & $2(16.7)$ & $2(16.7)$ & $5(41.7)$ & $3(25.0)$ & 12 \\
\hline East of Eastern Rift Valley & $15(16.5)$ & $20(22.0)$ & 17 (18.7) & $39(42.9)$ & 91 \\
\hline
\end{tabular}




\section{Isolation by Barrier Hypothesis}

There are significant differences in 2 of the 4 honk call parameters among geographic regions $\left(F_{12}\right.$, $302=2.246, p=0.010 ;$ Wilk's $\lambda=0.798$, partial $\left.\eta^{2}=0.73\right):$ unit length $\left(F_{3,117}=3.715, p=0.014\right)$, and interunit interval $\left(F_{3,117}=4.628, p=0.004\right)$, but not in dominant frequency or fundamental frequency. A Tukey post hoc test revealed that unit length in populations east of the Eastern Rift Valley is significantly different from populations west of the Eastern Rift Valley $(p=0.014)$. For interunit interval, $G$. senegalensis in the western-most part of the range (i.e., west of the Niger River) differs significantly from G. senegalensis in the eastern-most part of the range (i.e., east of the Eastern Rift Valley; $p=0.002$ ).

The DFA designated, on average, $42.1 \%$ of all honk calls to the correct geographic regions. Given that there are 4 regions, the probabilities for each is $25 \%$. Correct subspecies designation is highest for individuals east of the Eastern Rift Valley (42.9\%). Correct designation for individuals west of the Eastern Rift Valley (41.7\%) is better than by chance (Table 4). Individuals in the western-most part of the species' range and those in the eastern-most part of the species' range can be separated on DFA function 1 (which correlates most strongly with interunit length).

\section{DISCUSSION}

Comparison of acoustic features among and within taxa can provide a better understanding of their taxonomic arrangement, phylogenetic relationships, and ecological interactions [Hartmann et al., 2002]. This study is the first to describe and analyse intraspecies variation in the structure of the honk call of $G$. senegalensis, and its 4 subspecies, over its large geographic range. Three hypotheses were tested: isolation by distance hypothesis, genetic basis hypothesis, and isolation by barrier hypothesis. We found low to moderate levels of support for all three hypotheses.

The isolation by distance hypothesis predicts that subspecies with larger geographic ranges have more variation in their honk call than subspecies with small geographic ranges. Statistically significant support for the isolation by distance hypothesis was found for 2 of the 4 call parameters, as well as for all 4 parameters combined. Distance, however, explains only a moderate amount of the acoustic variation. 
The subspecies with the largest geographic range, G. s. senegalensis, shows no greater honk call variation than does G. s. braccatus, the subspecies with the smallest geographic range.

The genetic basis hypothesis predicts that honk call variation corresponds to the 4 subspecies recognised for G. senegalensis. While the absolute differences among these taxa are small and unmarked, we did find statistically significant acoustic differences in honk calls among the 4 subspecies for 3 of the 4 call parameters. These differences are most pronounced between G. s. senegalensis and G. s. dunni. It appears that temporal parameters, and to a lesser extent frequency parameters, are responsible for subspecies-level differences. This is in agreement with earlier studies. For example, Zimmermann [1990] measured interunit intervals for captive G. s. senegalensis and G. s. braccatus, and in accordance with our results, found higher interunit intervals for G. s. braccatus. Species-level differences, on the other hand, are often strongly reflected in differences in fundamental frequency and its modulation, in addition to differences in overall temporal patterns [Zimmermann et al., 1988; Zimmermann, 1990].

The isolation by barrier hypothesis predicts greater honk call variation between regions divided by putative geographic barriers. Sample sizes available to test this hypothesis are, unfortunately, small and unequal, potentially limiting the explanatory power of our analysis. Significant differences are, however, found in 2 of the 4 call parameters among the 4 geographic regions. Unit length of honk calls east of the Eastern Rift Valley is significantly different from populations west of the Eastern Rift Valley. This suggests that the Eastern Rift Valley serves, or has served, as a barrier for G. senegalensis, as it has for other primate species [Butynski and De Jong, 2007]. Likewise, the Niger River seems to act, or has acted, as a significant barrier.

Due to considerable morphological variation within G. senegalensis, Masters and Bragg [2000] postulate that there may be unrecognised taxa within this widespread species. However, the acoustic structures of the honk calls from the 28 sites ( 7 countries) included in this study are not noticeably different. This suggests that all 121 individuals sampled are G. senegalensis. This is not to say that unrecognised taxa within G. senegalensis do not occur - as vast geographic regions remain unsampled 
(e.g., the Sahel, the sub-Sahel, Ethiopia, Somalia, northern Kenya, Rwanda, Burundi, and western Tanzania; Fig. 1).

In addition to distance and isolation, divergence in acoustic signals among populations can be driven by various adaptive mechanisms. Variation in the acoustic structure of loud calls might be attributed to differences in morphology, including body size [Fitch and Hauser, 2003; Dávalos et al., 2018]. For example, small bats emit higher frequency calls than do larger bats [Jones, 1996]. In mammals, energy required for call production is generated in the lungs and calls are produced by vocal folds, subsequently modified in the vocal tract [Fitch and Hauser, 2003; Ey et al., 2007]. Larger mammals, therefore, can produce calls with lower fundamental and dominant frequencies than small mammals [Inoue, 1988; Fitch and Hauser, 1995]. This applies to some mammals, such as grasshopper mice (Onychomys spp.) [Hafner and Hafner, 1979], red deer (Cervus elaphus) [Reby et al., 2005], koalas (Phascolarctos cinereus) [Charlton et al., 2011], but not to others, such as ground squirrels (Spermophilus spp.) [Matrosova et al., 2007]. This study found that the lowest fundamental frequency and lowest dominant frequency occur in G. s. dunni, the largest subspecies (mean head-body length of $188 \mathrm{~mm}, n=$ 5) compared to the smaller G. s. senegalensis (mean head-body length $164 \mathrm{~mm}, n=55$ ) and $G$. $s$. braccatus (mean head-body length $164 \mathrm{~mm}, n=10$ ) [Nash et al., 2013]. It is, however, unlikely that honk call variation can be explained by the small differences in body size among these subspecies.

Apart from morphological cues, such as body size, differences in habitat structure drives natural selection for variation in mammal vocalizations, as in Gunnison's prairie dogs (Cynomys gunnisoni) [Perla and Slobodchikoff, 2002] and whistling rats (Parotomys spp.) [Le Roux et al., 2002]. Generally, taxa which prefer dense vegetation have vocalization with lower frequencies, narrower bandwidths, fewer frequency modulations, longer notes, and longer internote intervals [Morton, 1975]. Slower modulated elements are favoured in denser vegetation whereas longer calls with short, rapidly repeated elements perform better in open habitats [Wiley and Richards, 1978]. Galago senegalensis lives in a wide variety of habitats (woodland, bushland, riverine forest, moist forest) over a wide altitudinal range (0-2,800 m a.s.1.) [L. Ambrose, Y. de Jong, and T. Butynski, pers. observations]. Honk call diversity within $G$. 
senegalensis might, therefore, be partly explained by habitat structure. Unfortunately, systematic data on habitat structure were not always collected when this study's honk call recordings were made.

Some diurnal primates, such as ring-tailed lemur (Lemur catta), pygmy marmoset (Cebuella pygmaea), Japanese macaque, and Geoffroy's spider monkey (Ateles geoffroyi), adapt the acoustic structure of their loud call depending on the physical distance of the potential receiver [Snowdon and Hodun, 1981; Oda, 1996; Sugiura, 2007; Ordóñez-Gómez et al., 2017]; calls have a higher frequency as distance increases. This might be a mechanism to avoid environmental background noise and to increase localizability [Snowdon and Hodun, 1981; Oda, 1996; Sugiura, 2007]. This study did not assess whether the frequency of the honk call of G. senegalensis is influenced by intragroup dispersal. It is likely, however, that nocturnal primates which occur in small, dispersed groups adapt their loud call frequencies in response to the often ample environmental background noises.

As indicated earlier, geographic limits of all 4 G. senegalensis subspecies are, in most cases, poorly understood (Fig. 1). For example, although Hill [1953] suggests that the Blue Nile River is the western limit for G. s. dunni and the eastern limit for G. s. senegalensis, this remains to be validated. Similarly, the southern limit for G. s. dunni and the northern limit of G. s. braccatus are uncertain. It appears that G. s. sotikae meets G. s. senegalensis in the vicinity of Lake Edward, Lake George, and Katonga River, and again off the northeastern corner of Lake Victoria, but this is based on limited data.

Many primate taxa in Africa occur along phenotypic clines [Mayr, 1956]. In eastern Africa, this includes baboons (Papio spp.), savanna monkeys (Chlorocebus spp.), patas monkeys (Erythrocebus patas sspp.), and gentle monkeys (Cercopithecus mitis sspp.), as well as G. senegalensis [Jolly, 1993; Frost et al., 2003; De Jong and Butynski, 2009; Butynski and De Jong, 2012; Cardini et al., 2012; Y. de Jong and T. Butynski, pers. observations]. In Kenya, G. s. braccatus occurs east of the Eastern Rift Valley and G. s. sotikae occurs west of the Eastern Rift Valley as well as within the Rift Valley (Fig. 1). Butynski and De Jong [2012] recognise an east-west cline within G. senegalensis that extends from at least the Laikipia Plateau in central Kenya (G. s. braccatus), across the Eastern Rift Valley at Lake Naivasha, to at least Lake Manyara in central northern Tanzania (G. s. sotikae). The more obvious phenotypical changes along 
this cline are ear length and colour of the dorsum, outer hindlegs, and tail. Although this cline can be viewed in photographs available on the 'Galago Photographic Map' [De Jong and Butynski, 2018b], additional photographs from many more sites along this cline are required before the phenotypic changes can be described in detail. Although this cline calls into question the validity of G. s. braccatus and G. s. sotikae, this study found that honk call unit length and dominant frequency of individuals east of the Eastern Rift Valley are significantly different from those of individuals west of the Eastern Rift Valley. It may be that additional subspecies occur within G. senegalensis, and/or that more phenotypic clines will be detected. These should be sought as their presence and location will contribute to our understanding of the evolutionary history, biogeography, and taxonomy of $G$. senegalensis, and are likely to have important implications for the conservation of genetic, ecological, and behavioural diversity within this species.

The study of communication systems, and in particular vocalizations, in nocturnal primates, including night monkeys (Aotus spp.), tarsiers (Tarsiidae), lemurs (Lemuriformes), galagos, and lorises (Lorisinae), has revealed novel insights into the evolutionary history of these often cryptic animals. In some taxa, big differences in vocal behaviour and call types strongly suggest presence of multiple species. While variation in vocalizations is expected to be largest in wide-ranging species, G. senegalensis, the nocturnal primate with the largest geographic range, displays only minor differences in its calls. Other nocturnal species, when studied over large geographic scales, may exhibit similar uniformity or may markedly differ. Exploring this in more detail is an exciting and important avenue for further research.

\section{ACKNOWLEDGEMENTS}

We thank the editors of this special issue, K.A.I. Nekaris and S. Gursky-Doyen, for the invitation to contribute to this special issue, and L. Ambrose, C. Bettridge, G. Ellison, P. Honess, A. Perkin, R. Plesker, C.D. Schaaf, K. Schell, and J. Tombs for providing recordings of honk calls. We are grateful to S. Nash for the use of his drawing of G. s. dunni. We thank the three reviewers for the extensive and constructive comments that greatly improved this paper. 


\section{STATEMENT OF ETHICS}

The authors have no ethical conflicts to disclose.

\section{DISCLOSURE STATEMENT}

The authors have no conflicts of interest to declare.

\section{FUNDING SOURCES}

Fieldwork was funded by the following organisations: Conservation International, Critical Ecosystem Partnership Fund, Internal Grant Agency of the Czech University of Life Sciences in Prague, Kenya Wildlife Service, Margot Marsh Biodiversity Foundation, National Geographic Global Exploration Fund, the Nature Conservancy, Northern Rangeland Trust, Oxford Brookes University, Primate Action Fund, Primate Conservation Inc., Rhino Ark, the Wildlife Trust, Zoo Atlanta, and Zoo New England.

\section{AUTHOR CONTRIBUTIONS}

This project was conceived by M.S. Svensson and S.K. Bearder. M.S. Svensson, T.M. Butynski, Y.A. de Jong, S.K. Bearder, and I. Schneiderová collected field recordings of G. senegalensis. V. Nijman and M.S. Svensson analysed the data, and M.S. Svensson, T.M. Butynski, Y.A. de Jong, S.K. Bearder, I. Schneiderová, and V. Nijman wrote the paper. All authors approved the final manuscript.

\section{REFERENCES}

Anderson MJ (1999). The use of hand morphology in the taxonomy of galagos. Primates 40: 469-478. Anderson MJ (2001). The use of hair morphology in the classification of galagos (Primates, subfamily Galagoninae). Primates 42: 113-121. 
Anderson MJ, Ambrose L, Bearder SK, Dixon AF, Pullen S (2000). Intraspecific variation in the vocalization and hand pad morphology of southern lesser galagos, Galago moholi: a comparison with G. senegalensis. International Journal of Primatology 21: 537-555.

Baker MC, Baker EM, Baker MS (2003). Songs of the red-capped robin, Petroica goodenovii: comparison of acoustic features in island and mainland populations. Emu-Austral Ornithology 103: 329-335.

Bearder SK (1999). Physical and social diversity among nocturnal primates: a new view based on long term research. Primates 40: 267-282.

Bearder SK, Masters J (2013). Family Galagidae. In Mammals of Africa (Butynski TM, Kingdon J, Kalina J, eds.), vol II: Primates, pp 413-416. London, Bloomsbury.

Bearder SK, Honess PE, Ambrose L (1995). Species diversity among galagos with special reference to mate recognition. In Creatures of the Dark: The Nocturnal Prosimians (Alterman L, Doyle GA, Izard MK, eds.), pp 331-352. New York, Plenum Press.

Bearder SK, Ambrose L, Harcourt C, Honess P, Perkin A, Pimley E, Pullen S, Svoboda N (2003). Species-typical patterns of infant contact, sleeping site use and social cohesion among nocturnal primates in Africa. Folia Primatologica 74: 337-354.

Bettridge CM, Kenworthy SP, Butynski TM, De Jong YA, De Kort SR (in press). Vocal repertoire and intraspecific variation within two loud calls of the small-eared greater galago (Otolemur garnettii) in Tanzania and Kenya. Folia Primatologica This Volume.

Braune P, Schmidt S, Zimmermann E (2008). Acoustic divergence in the communication of cryptic species of nocturnal primates (Microcebus ssp.). BMC Biology 6: 19.

Brigham RM, Cebek JE (1989). Intraspecific variation in the echolocation calls of two species of insectivorous bats. Journal of Mammalogy 70: 426-428.

Burton JA, Nietsch A (2010). Geographical variation in duet songs of Sulawesi tarsiers: evidence for new cryptic species in south and southeast Sulawesi. International Journal of Primatology 31: 11231146. 
Butynski TM, De Jong YA (2004). Natural history of the Somali lesser galago (Galago gallarum). Journal of East African Natural History 93: 23-38.

Butynski TM, De Jong YA (2007). Distribution of the potto Perodicticus potto (Primates: Lorisidae) in eastern Africa, with a description of a new subspecies from Mount Kenya. Journal of East African Natural History 96: 113-147.

Butynski TM, De Jong YA (2012). Survey of the Primates of the Loita Hills, Kenya. Unpublished report to Primate Conservation Inc., Charlestown, Rhode Island. Available at: http://www.wildsolutions.nl/survey-primates-loita-hills-kenya/

Butynski TM, De Jong YA (2013). Galago gallarum Somali galago. In Mammals of Africa (Butynski TM, Kingdon J, Kalina J, eds.), vol II: Primates, pp 434-436. London, Bloomsbury.

Butynski TM, Kingdon J, Kalina J (2013). Mammals of Africa. Vol II: Primates. London, Bloomsbury. Campbell P, Pasch B, Pino JL, Crino OL, Phillips M, Phelps SM (2010). Geographic variation in the songs of Neotropical singing mice: testing the relative importance of drift and local adaptation. Evolution 64: 1955-1972.

Cardini A, Dunn J, O’Higgins P, Elton S (2012). Clines in Africa: does size vary in the same way among widespread sub-Saharan monkeys? Journal of Biogeography 40: 370-381.

Charlton BD, Ellis WA, McKinnon AJ, Cowin GJ, Brumm J, Nilsson K, Fitch WT (2011). Cues to body size in the formant spacing of male koala (Phascolarctos cinereus) bellows: honesty in an exaggerated trait. Journal of Experimental Biology 214: 3414-3422.

Clink DJ, Grote MN, Crofoot MC, Marshall AJ (2018). Understanding sources of variance and correlation among features of Bornean gibbon (Hylobates muelleri) female calls. Journal of the Acoustical Society of America 144: 698-708.

Conner DA (1982). Geographic variation in short calls of pikas (Ochotona princeps). Journal of Mammalogy 63: 48-52. 
Dallmann R, Geissmann T (2009). Individual and geographical variability in the songs of wild silvery gibbons (Hylobates moloch) on Java, Indonesia. In The Gibbons (Whittaker D, Lappan S, eds.), pp 91-110. New York, Springer.

Dávalos LM, Lancaster WC, Núñez-Novas MS, León YM, Lei B, Flanders J, Russell AL (2018). A coalescent-based estimator of genetic drift, and acoustic divergence in the Pteronotus parnellii species complex. Heredity 122: 417-427.

De Jong YA, Butynski TM (2009). Primate Biogeography, Diversity, Taxonomy and Conservation of the Coastal Forests of Kenya. Unpublished report by the Eastern Africa Primate Diversity and Conservation Program, Nanyuki. Available at: www.wildsolutions.nl

De Jong YA, Butynski TM (2018a). Primates of East Africa Pocket Identification Guide. Global Wildlife Conservation Tropical Pocket Guide Series, Austin, Texas. Available at: http://www.wildsolutions.nl/primates-east-africa-pocket-identification-guide/

De Jong YA, Butynski TM (2018b). Galago photographic map. Available at: www.wildsolutions.nl/photomaps/galago/

Delgado RA (2003). The Function of Adult Male Long Calls. PhD dissertation, Duke University, Durham.

DelPero M, Masters JC, Zuccon D, Cervella P, Crovella S, Ardito G (2000). Mitochondrial sequences as indicators of genetic classification in bush babies. International Journal of Primatology 21: 889904.

Ey E, Pfefferle D, Fischer J (2007). Do age-and sex-related variations reliably reflect body size in nonhuman primate vocalizations? A review. Primates 48: 253-267.

Fitch WT, Hauser MD (1995). Vocal production in non-human primates - acoustics, physiology, and functional constraints on honest advertisement. American Journal of Primatology 37: 191-219. Fitch W, Hauser M (2003). Unpacking "honesty": vertebrate vocal production and the evolution of acoustic signals. In Acoustic Communication (Simmons A, Fay R, Popper A, eds.), pp 65-137. New York, Springer. 
Ford JK (1991). Vocal traditions among resident killer whales (Orcinus orca) in coastal waters of British Columbia. Canadian Journal of Zoology 69: 1454-1483.

Frost SR, Marcus LF, Bookstein FL, Reddy DP, Delson E (2003). Cranial allometry, phylogeography, and systematics of large-bodied papionins (Primates: Cercopithecinae) inferred from geometric morphometric analysis of landmark data. The Anatomical Record Part A, Discoveries in Molecular, Cellular, and Evolutionary Biology 275: 1048-1072.

Green S (1975). Dialects in Japanese monkeys: vocal learning and cultural transmission of locale-specific vocal behavior? Zeitschrift für Tierpsychologie 38: 304-314.

Groves CP (2001). Primate Taxonomy. Washington, Smithsonian Institution Press.

Groves CP (2005). Order Primates. In Mammal Species of the World: A Taxonomic and Geographic Reference (Wilson DE, Reeder DM, eds.), vol 1, 3rd ed., pp 111-184. Baltimore, Johns Hopkins University Press.

Grubb P, Butynski TM, Oates JF, Bearder SK, Disotell TR, Groves CP, Struhsaker TT (2003). Assessment of the diversity of African primates. International Journal of Primatology 24: 13011357.

Hafner MS, Hafner DJ (1979). Vocalizations of grasshopper mice (genus Onychomys). Journal of Mammalogy 60: 85-94.

Hartmann MT, Hartmann PA, Haddad CF (2002). Advertisement calls of Chiasmocleis carvalhoi, Chiasmocleis mehelyi, and Myersiella microps (Microhylidae). Journal of Herpetology 36: 509511.

Hill AP, Prince P, Piña Covarrubias E, Doncaster CP, Snaddon JL, Rogers A (2018). AudioMoth: evaluation of a smart open acoustic device for monitoring biodiversity and the environment. Methods in Ecology and Evolution 9: 1199-1211.

Hill SD, Ji W, Parker KA, Amiot C, Wells SJ (2013). A comparison of vocalisations between mainland tui (Prosthemadera novaeseelandiae novaeseelandiae) and Chatham Island tui (P. $n$. chathamensis). New Zealand Journal of Ecology 37: 214-223. 
Hill WCO (1953). Primates: Comparative Anatomy and Taxonomy. Vol I: Strepsirhini. Edinburgh,

Edinburgh University Press.

Honess, PE (1996). Speciation among Galagos (Primates, Galagidae) in Tanzanian Forests. PhD thesis, Oxford Brookes University, Oxford.

Inoue M (1988). Age gradations in vocalization and body weight in Japanese monkeys (Macaca fuscata). Folia Primatologica 51: 76-86.

Irwin DE, Thimgan MP, Irwin JH (2008). Call divergence is correlated with geographic and genetic distance in greenish warblers (Phylloscopus trochiloides): a strong role for stochasticity in signal evolution? Journal of Evolutionary Biology 21: 435-448.

Jenkins PD (1987). Catalogue of Primates in the British Museum (Natural History) and Elsewhere in the British Isles. Part 4: Suborder Strepsirrhini, Including the Subfossil Madagascan Lemurs and Family Tarsiidae. London, British Museum (Natural History).

Jolly CJ (1993). Species, subspecies, and baboon systematics. In Species, Species Concepts and Primate Evolution. Advances in Primatology (Kimbel WH, Martin LB, eds.), pp 67-107. Boston, Springer. Jones G (1996). Does echolocation constrain the evolution of body size in bats? In Symposia of the Zoological Society of London 1960-1999 (Miller PJ, ed.), pp 111-128. London, Zoological Society of London.

Jones G, Van Parijs SM (1993). Bimodal echolocation in pipistrelle bats: are cryptic species present? Proceedings of the Royal Society of London B 251: 119-125.

Kingdon J (1997). The Kingdon Field Guide to African Mammals, 1st ed. London, Academic Press.

Le Roux A, Jackson TP, Cherry MI (2002). Differences in alarm vocalizations of sympatric populations of the whistling rats, Parotomys brantsii and P. littledalei (Rodentia: Muridae). Journal of Zoology 257: 189-194.

Maeda T, Masataka N (1987). Locale-specific vocal behaviour of the tamarin (Saguinus l. labiatus). Ethology 75: 25-30. 
Masters JC (1993). Primates and paradigms: problems with the identification of genetic species. In Species, Species Concepts and Primate Evolution (Kimbel WH, Martin LB, eds.), pp 43-64. New York, Plenum Press.

Masters JC, Bragg NP (2000). Morphological correlates of speciation in bush babies. International Journal of Primatology 21: 793-813.

Masters JC, Boniotto M, Crovella S, Roos C, Pozzi L, DelPero M (2007). Phylogenetic relationships among the Lorisoidea as indicated by craniodental morphology and mitochondrial sequence data. American Journal of Primatology 69: 6-15.

Matrosova VA, Volodin IA, Volodina EV, Babitsky AF (2007). Pups crying bass: vocal adaptation for avoidance of age-dependent predation risk in ground squirrels? Behavioral Ecology and Sociobiology 62: 181-191.

Mayr E (1956). Geographical character gradients and climatic adaptation. International Journal of Organic Evolution 10: 105-108.

Mitani JC, Hunley KL, Murdoch ME (1999). Geographic variation in the calls of wild chimpanzees: a reassessment. American Journal of Primatology 47: 133-151.

Morton ES (1975). Ecological sources of selection on avian sounds. The American Naturalist 109: 17-34. Nash LT, Bearder SK, Olson T (1989). A synoptic overview of galago species differences. International Journal of Primatology 10: 57-80.

Nash LT, Zimmermann E, Butynski TM (2013). Galago senegalensis northern lesser galago. In Mammals of Africa (Butynski TM, Kingdon J, Kalina J, eds.), vol II: Primates, pp 425-429. London, Bloomsbury.

Nekaris KAI (2013). Galagidae. In Handbook of the Mammals of the World (Mittermeier RA, Rylands AB, Wilson DE, eds.), vol III: Primates, pp 184-209. Barcelona, Lynx.

Nekaris KAI, Bearder SK (2011). The lorisiform primates of Asia and mainland Africa: diversity shrouded in darkness. In Primates in Perspective (Campbell CJ, Fuentes A, MacKinnon KC, Bearder SK, Stumpf RM, eds.), pp 34-54. Oxford, Oxford University Press. 
Oda R (1996). Effects of contextual and social variables on contact call production in free-ranging ringtailed lemurs (Lemur catta). International Journal of Primatology 17: 191-205.

Olson TR (1979). Studies on Aspects of the Morphology and Systematics of the Genus Otolemur (Coquerel, 1859) (Primates: Galagidae). PhD thesis, University of London, London.

Ordóñez-Gómez JD, Santillán-Doherty AM, Fischer J, Hammerschmidt K (2018). Acoustic variation of spider monkeys' contact calls (whinnies) is related to distance between vocalizing individuals and immediate caller behavior. American Journal of Primatology 80: e22747.

Perla BS, Slobodchikoff CN (2002). Habitat structure and alarm call dialects in Gunnison's prairie dog (Cynomys gunnisoni). Behavioral Ecology 13: 844-850.

Pozzi L, Nekaris KAI, Perkin A, Bearder SK, Pimley ER, Schulze H, Streicher U, Nadler T, Kitchener A, Zischler H, Zinner D, Roos C (2015). Remarkable ancient divergences amongst neglected lorisiform primates. Zoological Journal of the Linnean Society 175: 661-674.

Price T, Ndiaye O, Hammerschmidt K, Fischer J (2014). Limited geographic variation in the acoustic structure of and responses to adult male alarm barks of African green monkeys. Behavioral Ecology and Sociobiology 68: 815-825.

Reby D, McComb K, Darwin C, Fitch WT (2005). Formant frequencies as indicators of body size in red deer roars. The Journal of the Acoustical Society of America 117: 2373-2373.

Roos C, Schmitz J, Zischler H (2004). Primate jumping genes elucidate strepsirrhine phylogeny. Proceedings of the National Academy of Sciences 101: 10650-10654.

Rowe N, Myers M (2016). All the World's Primates. Charlestown, Pogonias Press.

Schneiderová I, Zouhar J, Štefanská L, Bolfíková BČ, Lhota S, Brandl P (2016). Vocal activity of lesser galagos (Galago spp.) at zoos. Zoo Biology 35: 147-156.

Schwarz E (1931). On the African long-tailed lemurs or galagos. Annals and Magazine of Natural History 10: 41-66.

Slobodchikoff CN, Ackers SH, Van Ert M (1998). Geographic variability in alarm calls of Gunnison's prairie dogs. Journal of Mammalogy 79: 1265-1272. 
Snowdon CT, Hodun A (1981). Acoustic adaptation in pygmy marmoset contact calls: locational cues vary with distances between conspecifics. Behavioral Ecology and Sociobiology 9: 295-300.

Sugiura H (2007). Effects of proximity and behavioral context on acoustic variation in the coo calls of Japanese macaques. American Journal of Primatology 69: 1412-1424.

Svensson MS, Bearder SK (2013). Sightings and habitat use of the northern lesser galago (Galago senegalensis senegalensis) in Niumi National Park, The Gambia. African Primates 8: 51-58.

Svensson MS, Bersacola E, Mills MSL, Munds RA, Nijman V, Perkin A, Masters JC, Couette S, Nekaris KAI, Bearder SK (2017). A giant among dwarfs: a new species of galago (Primates: Galagidae) from Angola. American Journal of Physical Anthropology 163: 30-43.

Turner DA (2011). The montane nightjars (family Caprimulgidae) of eastern Africa. Scopus: Journal of East African Ornithology 31: 32-34.

Velásquez NA (2014). Geographic variation in acoustic communication in anurans and its euroethological implications. Journal of Physiology Paris 108: 167-173.

Wich SA, Schel AM, de Vries H (2008). Geographic variation in Thomas langur (Presbytis thomasi) loud calls. American Journal of Primatology 70: 1-9.

Wiley RH, Richards DG (1978). Physical constraints on acoustic communication in atmosphere implications for evolution of animal vocalizations. Behavioral Ecology and Sociobiology 3: 6994.

Wilkins MR, Seddon N, Safran RJ (2013). Evolutionary divergence in acoustic signals: causes and consequences. Trends in Ecology and Evolution 28: 156-166.

Wright S (1943). Isolation by distance. Genetics 28: 114-138.

Wright TF, Dahlin CR (2018). Vocal dialects in parrots: patterns and processes of cultural evolution. Emu-Austral Ornithology 118: 50-66.

Yuan CLT, Ramli DA (2013). Frog Sound Identification System for Frog Species Recognition. In Context-Aware Systems and Applications (Vinh PC, Hung NM, Tung NT, Suzuki J, eds.), pp. 4150. Berlin Heidelberg, Springer. 
Zimmermann E (1985). The vocal repertoire of the adult Senegal bushbaby (Galago senegalensis senegalensis). Behaviour 94: 212-233.

Zimmermann E (1990). Differentiation of vocalizations in bushbabies (Galaginae, Prosimiae, Primates) and the significance for assessing phylogenetic relationships. Journal of Zoological Systematics and Evolutionary Research 28: 217-239.

Zimmermann E (1995). Acoustic communication in nocturnal prosimians. In Creatures of the Dark: The Nocturnal Prosimians (Alterman L, Doyle GA, Izard MK, eds.), pp 311-330. New York, Plenum Press.

Zimmermann E, Bearder SK, Doyle GA, Andersson AB (1988). Variations in vocal patterns of Senegal and South African lesser bushbabies and their implications for taxonomic relationships. Folia Primatologica 51: 87-105. 